$5-31-2019$

\title{
Does institutional ownership affect information sharing with independent board members?
}

\author{
Deborah D. Smith \\ Cleveland State University, d.I.smith11@csuohio.edu \\ Heidi H. Meier \\ Cleveland State University, h.meier@csuohio.edu \\ Pervaiz Alam \\ Kent State Unviersity
}

Follow this and additional works at: https://engagedscholarship.csuohio.edu/bus_facpub

Part of the Accounting Commons

How does access to this work benefit you? Let us know!

\section{Publisher's Statement}

This is the peer reviewed version of the following article: Smith, D., Meier, H., \& Alam, P. (2019).

Does institutional ownership affect information sharing with independent board members?

Journal of Corporate Accounting and Finance, 30(4), doi.org/10.1002/jcaf.22403, which has been published in final form at https://doi.org/10.1002/jcaf.22403. This article may be used for non-commercial purposes in accordance with Wiley Terms and Conditions for Use of SelfArchived Versions.

\section{Recommended Citation}

Smith, Deborah D.; Meier, Heidi H.; and Alam, Pervaiz, "Does institutional ownership affect information sharing with independent board members?" (2019). Business Faculty Publications. 317.

https://engagedscholarship.csuohio.edu/bus_facpub/317

This Article is brought to you for free and open access by the Monte Ahuja College of Business at EngagedScholarship@CSU. It has been accepted for inclusion in Business Faculty Publications by an authorized administrator of EngagedScholarship@CSU. For more information, please contact library.es@csuohio.edu. 


\title{
Does institutional ownership affect information sharing with independent board members?
}

\author{
Deborah D. Smith | Heidi H. Meier | Pervaiz Alam
}

\begin{abstract}
Research Question: This is an investigation of board independence to determine whether management shares information with the board, or withholds information to retain autonomy. A key contribution is to examine the interaction of institutional ownership with the main test variables to determine whether institutional governance influences the information environment as board independence is increased.

Research Findings: The results show that information asymmetry decreases internally and increases externally as board independence increases, yet institutional ownership appears to moderate or reverse this relationship. The following variables are used to explain why managers of firms are likely to have more information than outsiders: sticky SG\&A costs, bid-ask spread, and forecast error.

Theoretical/Academic Implications: The desired oversight from independent board members appears to be associated with reduced transparency between the firm and investors. Information sharing is lower for increased board independence when the firm's ownership is less sophisticated.

Practitioner/Policy Implications: These findings suggest that requiring increased board independence may reflect reduced transparency for firms with less institutional ownership. Further research should be conducted on the influence of institutional ownership on board member selection, and the relationship between management and board members appointed with institutional support.
\end{abstract}

KE Y W O R D S

agency theory, board independence, corporate governance, information asymmetry, sticky costs

\section{1 | INTRODUCTION}

Ideally, corporate governance should align the interest of shareholders, board of directors and managers. The role of financial reporting is to reduce information asymmetry between mangers and the investment community. Therefore, there is a need for transparency in the financial reporting environment of the firm. Additionally, the board of directors should have the expertise and independence to advise the managers. Outside directors bring independence and objectivity in monitoring management whereas inside directors have firm-specific information about resources and opportunities which could prove useful for the board. Many of the prior studies on board independence did not control for institutional ownership, which reached $75 \%$ of the market in 2005 (Davidoff, 2013), yet the influence of this more sophisticated ownership has the potential to affect board size and composition. The increase in institutional ownership over time has strengthened shareholder power in determining CEO and director appointments and replacements through activism. As management and institutional owners negotiate for sway over 
the selection of board members, the firm's information environment may hang in the balance.

The objective of this study is to shed light on the information environment of corporate boards as they increase board independence. Recent federal regulation and stock exchange requirements have put pressure on firms to increase independent membership (Linck, Netter, \& Yang, 2008). Independent board members are expected to provide managerial oversight, and to augment the expertise and perspective available for management decisions, but in order to advise management, these outsiders require information about the operation of the firm. Although management can benefit from their expertise, managers may withhold information from the board to protect existing perquisites and operational preferences or to hide poor performance, in effect reducing the ability of independent board members to contribute. Board members are not all equally qualified. Some have more knowledge of the industry or have a specific area of expertise, and some independent board members have informal relationships with management, making them independent only in appearance. The objective of this study is to identify information asymmetry associated with increased board independence by testing the board's communication with management, analysts, and investors.

An important distinction of this study is the investigation of how institutional ownership affects the addition of independent board members. The composition of corporate boards is increasingly influenced by institutional owners (Smith, 1996). The prevalence of institutional owners has grown from 7\% in 1950 to approximately $67 \%$ of publicly-traded equity in 2010 , and more institutional owners are taking on an activist role (Aguilar, 2013). There are many accounts in recent news of institutions using proxy wars or legal action to affect acquisitions, board selection, and CEO turnover. For example, when Target Corporation had a large data breach of customer credit cards, Institutional Shareholder Services (ISS) lobbied against the seven board members for their lack of diligence regarding the security threat (D'Innocenzio, 2014). Westphal and Bednar (2008) explain that CEO's try to ingratiate themselves with institutional owners since the power institutions hold to shape board composition also extends to the longevity of the CEO. A case in point, Starboard Value LP placed three members on the board of Darden Restaurants, Inc. and forced the CEO, Clarence Otis, to step down (Benoit \& Jargon, 2014). Sur, Lvina, and Magnan (2013) find that higher institutional ownership results in more independent boards, and they argue that owners influence the board member selection process. This study's hypothesis and finding is that institutional ownership affects the information environment of the board of directors, analysts, and investors.

There is no sure way of measuring information asymmetry, consequently prior studies have used various proxies (Byard, Li, \& Weintrop, 2006; Goh et al., 2016). In this study, the selected proxies for information asymmetry are sales, general, and administrative expenses (SG\&A), bid-ask spread, and analysts' forecast error. In addition, this study takes into account the role of institutional investors in reducing information asymmetry between the board and managers.

SG\&A expenses are semi-fixed, so they should fluctuate roughly with increases or decreases in sales. However, research has shown that, on average, management increases SG\&A expenses with sales growth, but is slower to cut SG\&A expenses with sales declines. The computed difference between the rate these expenses are cut with sales declines, versus the rate SG\&A expenses increase with sales growth, is referred to as the "stickiness" of SG\&A costs. SG\&A includes sales expenses, and administrative and assistant salaries, along with items such as company provided transportation, offices and services that management may be reluctant to reduce. The regression results show that SG\&A costs are less sticky in firms that add more outside members to their board of directors, indicating that information sharing between management and the board facilitates tight monitoring of the firm's SG\&A costs. In the examination of information asymmetry with analysts and investors, this study finds that higher board independence reduces transparency indicating that higher board independence does not necessarily lead to higher information sharing between the firm and investment community.

Costs are stickier with higher institutional ownership as board independence increases, suggesting that the institutional influence on board member selection decreases cooperation internally, between management and the board. Externally, with analysts and investors, the findings imply that institutional ownership has a mitigating effect on the positive association between information asymmetry and board independence.

\section{2 | RELATED LITERATURE AND HYPOTHESES}

The first section of the literature review, "Board Independence," discusses board independence and the costs and benefits of information sharing by the board. The second section, "Information Asymmetry and Board Independence," introduces the proxies for information asymmetry.

\section{1 | Board independence}

Corporate boards generally include outside and inside directors. Davidoff (2013) reports that independent directors have grown from $20 \%$ of their boards in 1950 to $75 \%$ in 2005 . Following 82 manufacturing firms, Lehn, Patro, and Zhao (2009) find an increase in inside board members from 1935 to 1960 , followed by a decrease from a mean of 6.03 in 1960 to 1.77 in 2000, which was coupled with a decrease in overall board size. The number of inside board members has increased in the post-SOX era (Linck et al., 2008), although some studies caution that the percentage of outsiders on the board is highly dependent on firm specific 
factors (Coles, Daniel, \& Naveen, 2008; Guest, 2008; Lehn et al., 2009; Raheja, 2005).

It is generally expected that experienced independent outside directors are able to provide critical insight which sometime is lacking in all or mostly insider boards. On the other hand, outside directors have to make the extra effort to understand and educate themselves regarding operational and strategic matters of the firm. Self-learning and information acquisition for outside board members may not be as easy since it involves time, money, and effort. Thus, it is likely that outside members of the board of directors may not be as effective in advising the CEO as inside members. Instead these outside directors may end up relying on inside managers or inside directors for information necessary to make their decisions (Armstrong, Guay, \& Weber, 2010).

Inside directors, who are often executives of the firm, generally have a better understanding of the firm relative to outside directors regarding operational, financial, and investment matters. They are likely to be better able to assist the board in its decision-making role. Conversely, inside directors may not be willing to share inside information that easily, particularly if they perceive that the more informed outsiders may become an impediment in the implementation of the CEO's preferences (Adams \& Ferreira, 2007). Further, more powerful CEOs are less likely to share information with the board (Withisuphakorn \& Jiraporn, 2015), and CEOs may try to ingratiate themselves with the board to gain sympathy for their preferred initiatives and higher pay (Schwartz-Ziv \& Weisbach, 2013). Alternatively, a board made of mostly inside directors would lack the objectivity necessary to advise the CEO in the best interest of the firm.

An independent board may not serve the interest of the stockholders if they do not have information necessary to serve as effective monitors and advisors, particularly in complex firms facing high risk and dynamic investment opportunities. In such settings, the inside directors are likely to have a better understanding of the various risks and opportunities available to the firms. Therefore, it is likely that information asymmetry between the outside directors and managers are more severe in firms in competitive industries and in firms with sizable investments in research and development and intangibles.

Harris and Raviv (2006) provide a theoretical examination of firm performance under insider versus outsider directors. The authors propose challenges to the conventional opinion that outsider-dominated boards are better for shareholders. Harris and Raviv (2006) explain that either side, inside board members or independent board members, may use their own information, or they may transfer the decision to the other party. If outsiders are in control and do not have enough information, they may yield control to the more knowledgeable insiders or retain control in spite of having inadequate information. If insiders are in control, they will not yield control to poorly informed outsiders, so under these circumstances an insider controlled board may benefit shareholders. Another problem with a large number of outsiders on the board is the potential for free-riders. As outsiders are added to the board, they share their expertise, but as the number of outsiders on the board increases, directors may contribute less because they feel that their expertise is less valuable (Harris \& Raviv, 2006). Harris and Raviv (2006) also show that external shocks affect the firm's optimal balance of board independence and size.

Boone, Field, Karporr, and Raheja (2007) examine the board size and composition of firms from their IPO in the period from 1988 to 1992 through the first 10 years of the firms' life. The authors determine that board size and independence increases over the life of the firm. They find that boards become more independent and larger over time, that the costs and benefits of monitoring affect board size but not board independence, and their findings suggest that managerial power influences the percentage of board independence. More board independence provides benefits such as monitoring of management's opportunities for personal benefit: free cash flow, industry concentration, and enhanced takeover defenses as measured by the GIndex. On the other hand, costs of monitoring represent learning curves for outsiders to understand the firm. Proxies for this complexity include a lower marketto-book ratio, high R\&D expense, and higher return variance. Another cost of monitoring is that increased monitoring is correlated endogenously with higher CEO ownership.

Complex firms benefit from having more outsiders on the board and by increasing the size and independence of the board (Coles et al., 2008). Examining a sample of firms between 1992 and 2001, Coles et al. (2008) determine that, in general, firm value increases for complex firms with larger boards, but firm value decreases for simple firms with larger boards. The authors define complex firms by size, debt ratio, and diversification. Their results indicate that when the knowledge requirements for firm management are highly firm-specific, such as with technology firms, having more insiders on the board increases firm value.

\section{2 | Information asymmetry and board Independence}

Several researchers have examined the relationship between the characteristics of members of boards of directors and information asymmetry. In previous studies, proxies for information asymmetry represent information shared externally with the market and analysts, for example, bid-ask spread (Fehle, 2004; Goh, Lee, Ng, \& Ow Yong, 2016; Kanagaretnam, Lobo, \& Whalen, 2007; Linck et al., 2008), analyst following (Goh et al., 2016; Shiah-Hou, 2011), and forecast error (Byard et al., 2006; Goh et al., 2016). Linck et al. (2008) set a 
combined proxy with bid-ask spread, R\&D costs and marketto-book ratio to determine that higher volatility results in less independent boards.

Some prior research investigates information asymmetry from an inside perspective, between management and the board of directors. Information acquisition is more costly when it is more difficult for new directors to become informed on the firm's operations and strategy (Linck et al., 2008). For example, growth firms and technology firms may have more insider information that new directors must become familiar with in order to contribute to board monitoring. When information acquisition and processing cost is higher for the outside directors, higher information asymmetry results. Lehn et al. (2009) and Linck et al. (2008) show that the proportion of outside directors is lower in firms where information acquisition is higher. Cai, Garner, and Walkling (2009) report that firms with a higher degree of information asymmetry have lower proportion of independent directors.

\subsection{Hypothesis development}

In this study, information asymmetry is evaluated from the perspective of the firm's management to evaluate information sharing with the market, analysts, and board of directors. Measures of information asymmetry, discussed individually below, include selling, general, and administrative expenses (SG\&A), bid-ask spread, and forecast error. The objective is to investigate the autonomy and information asymmetry related to increased independence on the board of directors, taking into account the influence of institutional ownership.

\subsection{1 | Institutional ownership and board independence}

The influence of institutional owners has increased over time as their percentage ownership increases to over $75 \%$ of publicly traded equity, and more institutional owners are taking on an activist role (Aguilar, 2013). Bebchuk (2005) recommends providing shareholders more power in the selection and retention of directors. Sur et al. (2013) use a Granger causality model to support that ownership composition determines board composition. Rock (2015) explains that not all institutional owners are activists, and institutional shareholders often use an exit strategy rather than activism to effect change.

McCahery, Sautner, and Starks (2016) conduct a survey of institutional owners to determine the methods of influence they use and the extent to which institutional owners participate in firm governance. Their survey reveals that, “...63\% of respondents state that in the past five years they have engaged in direct discussions with management, and $45 \%$ state that they have had private discussions with a company's board outside of management's presence." McCahery et al. (2016) determine that, even though some passive institutional owners use proxy services, they use them more as a compliment to other information rather than relying solely on the proxy service for advice on voting. The authors find that influence comes from institutional owners with longer intended holding periods and does not appear to be driven by a select group of activists. In addition to using their voice to sway board decisions, institutional owners may use the threat to exit their ownership as a means of effecting change in the firm, especially over governance concerns (McCahery et al., 2016).

The influence of institutional ownership on firm boards is not limited to hedge funds and activists. Schmidt and Fahlenbrach (2017) examine the effects of changes in passive institutional ownership. Their sample is chosen from the realignment of the Russel 2000 and the passive institutional owners of index funds that adjust holdings based on the Schmidt and Fahlenbrach (2017) changes in the index. A central conclusion of the Schmidt and Fahlenbrach (2017) study is that an increase in passive institutional ownership results in a higher concentration of CEO power. Furthermore, Schmidt and Fahlenbrach (2017) also find that when passive institutional ownership in a firm increases, the quality of governance in the firm is affected, and the appointment of new board members is met with negative announcement returns.

\subsubsection{SG\&A costs and board independence}

The function of the board is to provide advice and oversight, yet recent literature has documented that CEO's have power over the board of directors (Bebchuk, Fried, \& Walker, 2002). Management may prefer to withhold information to protect their perquisites and avoid the difficult task of reducing administrative personnel or SG\&A costs when sales decline or to protect their autonomy. Adams and Ferreira (2007) explain that managers may not want to share information that would reveal management mistakes, personal preferences or perquisites. Management may resist sharing information with a strong monitoring board in order to retain control (Adams \& Ferreira, 2007). To measure the extent of information asymmetry between management and the board of directors, this study uses sticky SG\&A costs.

Some recent research has documented that there may be strategic reasons for holding SG\&A costs higher when sales activity declines (Anderson, Banker, Huang, \& Janakiraman, 2007; Baumgarten, Bonenkamp, \& Homburg, 2010), but SG\&A costs have been used in a number of studies to proxy for agency cost. Since agency costs are the product of information asymmetry, SG\&A costs are used to represent information asymmetry between management and the board of directors. 
Bertrand and Mullainathan (2003) argue that most managers have additional slack because they prefer to avoid tough decisions to downsize. Singh and Davidson III (2003) explain that management may use advertising and selling expense accounts to conceal perquisites. The authors use SG\&A costs to proxy for excessive pay and perquisite expenditures for management such as offices, cars, and furnishings, and find that managerial ownership does not significantly deter management from overspending in administrative expenses. Chen and Yur-Austin (2007) use SG\&A costs to proxy for "management extravagance." They find that managerial blockholders do not have a significant effect in reducing managerial extravagance, but outside blockholders provide oversight. Jelinek and Stuerke (2009) explain that the components of SG\&A costs capture managerial pay and perquisites including salaries, rents, insurance, company transportation, and office furnishings. They identify a nonlinear relationship between managerial equity ownership and SG\&A. While at moderate levels of managerial ownership SG\&A costs are lower, managers with the highest equity ownership had relatively higher SG\&A costs, and in some industries, higher ownership led to strictly higher SG\&A costs. SG\&A costs are used as a proxy for agency costs by Florackis and Ozkan (2009) in their investigation of UK firms and by Koo (2011), in the form of sticky SG\&A costs, with Korean firms.

Bruggen and Zehnder (2014) find that sticky SG\&A costs are higher when management receives entirely equity compensation. The authors interpret this as an indication that higher sticky costs must not be due to empire-building because the equity compensation aligns management with shareholders. However, Harford and Li (2007) document that the bulk of the payment to empire-building CEO's who engage in valuedestroying acquisitions is made with "incentive-aligning" stock grants, and in their sample, the median CEO wealth increases by $\$ 10$ million in the year after acquisition, primarily paid to CEOs in the form of stock grants. Jelinek and Stuerke (2009) point out that, "At some level, equity ownership will cease to align the interest of management with that of shareholders, as managers will derive more benefit from the direct consumption of perquisites than from their pro rata share of firm profits." It is possible that some of the all-equity compensated CEO's in the Bruggen and Zehnder (2014) sample are engaged in empire-building, which may explain the finding by Chen, $\mathrm{Lu}$, and Sougiannis (2012).

Sticky SG\&A costs have been linked to CEO power over the board of directors and overinvesting management as an agency cost (Chen et al., 2012). The associated characteristics of empire-building and CEO power were identified by Grinstein and Hribar (2004) as well. They find that the most powerful CEOs make larger acquisitions, get paid twice the deal size to do it, are more likely to acquire, and have the lowest returns from acquisition. Consequently, it is expected that CEO's have the power to withhold information about future sales declines when communicating with their board to avoid reducing SG\&A agency-related costs.

The measure of sticky SG\&A costs is employed to proxy for the information shared between management and independent representatives on the board of directors because SG\&A costs are entirely controllable by management and are not directly controllable by any other entity. These costs are semi-fixed and firms must plan in advance to adjust them to expected changes in activity. Information ex-post regarding SG\&A costs is available via quarterly reports to analysts and investors, but whether more timely and detailed information is provided and explained to the board of directors is representative of the information sharing between management and the board. Management can influence the selection of board members, share information about the inside expectations of immediate sales changes, and improve firm performance by drawing on the expertise of external board members. Therefore, it is expected that more independent boards will be explained by less sticky costs as management influences board member selection and gains from external board member advice. More independent boards should have less information asymmetry between management and the board. The following hypothesis is tested to examine the relationship between sticky SG\&A costs and board independence.

H1a Firms with less sticky SG\&A costs have a higher percentage of board independence.

\subsubsection{Information asymmetry with the market and board independence}

To proxy for information sharing with the market this study uses the bid-ask spread. Board independence has been identified in prior literature to decrease bid-ask spread. Using a sample of quarterly earnings announcements in the year 2000, Kanagaretnam et al. (2007) document that the bid-ask spread due to quarterly earnings announcements is smaller when the firm has more independent board members. They use bid-ask spread at the point of earnings announcements in the year, 2000 , as a measure of information asymmetry. The authors conclude that firms with better governance provide more frequent, and accurate, disclosures that lower information asymmetry. Cai et al. (2009) use a sample of firms through 2003, finding a negative relationship between information asymmetry and board independence. This research uses samples that end prior to or shortly after the implementation of SOX and Regulation Fair Disclosure (Reg FD, implemented in October, 2000). These studies do not consider the role of institutional ownership in influencing management to provide more information to the board and the market. 
During the period where board independence was increasing to comply with regulation from the exchanges and SOX, Reg FD restricted the private conversations with firm management and analysts. Sample periods for prior studies do not extend as far beyond the implementation of these two regulatory events. The results in prior literature are mixed, but some studies document an increase in bid-ask spread for the post-Reg FD period. Straser (2002) finds an increase in the adverse selection component of bid-ask spread. The adverse selection pricing component reflects the information asymmetry in the market and is one of three components of the bid-ask spread (the other two being inventory and processing costs). Sidhu, Smith, Whaley, and Willis (2008) also conclude that fewer disclosures increase the bid-ask spread after Reg FD. Gomes, Gorton, and Madureira (2007) find that Reg FD caused a realignment in analyst coverage (see also, Mohanram \& Sunder, 2006), which negatively affects information asymmetry for small or complex firms because it is more difficult for those firms to share information directly with the market. The period after Reg FD coincides with the regulatory increases in board independence, so this is expected to increase the positive association between board independence and information asymmetry. In consideration of this previous research, the hypothesis is presented as follows.

H1b Firms with higher bid-ask spread will have higher board independence.

\subsubsection{Information asymmetry with analysts and board independence}

To measure information asymmetry between management and analysts, this study uses the proxy, forecast error. Due to the passage of Regulation Full Disclosure (Reg-FD) of the Securities and Exchange Commission, as well as the greater scrutiny and legal liability imposed by Sarbanes Oxley Act of 2002, information asymmetry between the firm and analysts has increased over time (Cai et al., 2009). Byard et al. (2006) determine that forecast error is reduced with improved corporate governance such as board independence. Their sample methodology controls for institutional ownership in a sample of firms prior to Sarbanes-Oxley, 2000-2002.

Goh et al. (2016) use a more recent sample from 1997 through 2006. They extend controls for board independence to include connections with other boards, and they also find lower information asymmetry with increased outside influence on the board. Using path analysis, they determine that lower bid-ask spread is most influenced by increased analyst coverage, which is due to strong governance and high board independence. If higher analyst coverage reduces forecast error, then it is possible that forecast error increased due to Reg FD, because analyst following in the post-Reg FD period is lower according to a study by Mohanram and Sunder (2006). Mohanram and Sunder (2006) examine analyst coverage after Reg FD and determine that analysts cover fewer firms because of the additional work required to obtain information post-Reg FD. Thus, analysts change from following firms with heavy analyst coverage and instead follow firms where they can develop an analyst expertise. Firms that had more private communication with analysts lost more of their analyst following due to Reg FD than firms that did not share as much private information. The results of prior studies are mixed, but several studies document an increase in forecast error in the post-Reg FD period (Agrawal, Chadha, \& Chen, 2006; Mohanram \& Sunder, 2006; Topaloglu, 2003) during the same period that board independence increased. Furthermore, it is expected that firms with more board independence are closely monitored, and are likely to adhere to the Reg-FD rules more stringently, which would increase information asymmetry. Therefore, the information asymmetry external to the firm may be increased with more intense board monitoring.

H1c Firms with higher forecast error will have higher board independence.

\subsection{5 | Mitigating effect of institutional ownership on information asymmetry}

Some prior studies on the relationship of board independence to information asymmetry include a control for institutional ownership, but many do not. There is ample evidence that institutional owners play a considerable role in board independence and information asymmetry. The slate of outside board members is typically selected by management and voted on by shareholders (Bebchuk et al., 2002). When a more concentrated base of institutional owners hold sway over the process, management has less control over the selection of external board members and communication is likely to be less transparent. Furthermore, institutionally influenced, external board members may be more zealous in oversight of management's perquisites, forcing managers to extract rents by concealing them within SG\&A expenses.

Akins, Ng, and Verdi (2012) show that institutional shareholders seek out firms with better governance, including those with more independent boards. Fehle (2004) identifies a negative relationship between the bid-ask spread and the magnitude and type of institutional ownership. Cheng, Luo, and Yue (2013) find that management alters its forecast precision for self-servicing purposes to facilitate better returns on insider trades, however institutional was found to mitigate this activity. For firms with high institutional ownership, Cheng et al. (2013) 
document a weaker relationship between forecast precision and managerial stock trades. Therefore, it is expected that the expertise, capital market relationships, and ownership influence contributed by institutional shareholders decreases information asymmetry for investors and analysts.

H2 Institutional ownership moderates the effect of information asymmetry.

\section{3 | RESEARCH DESIGN}

\subsection{Model specification}

The relationship of information asymmetry between managers and outside directors is tested by adopting a model from Linck et al. (2008). The model is fitted with and without interaction with institutional ownership. The equation is as follows:

$$
\begin{aligned}
\text { PercentInd }= & \beta_{0}+\beta_{1} \text { Information Asymmetry } \\
& +\beta_{2} \text { Information Asymmetry } \times \text { InstOwnPerc } \\
& +\beta_{3} \text { Controls }+ \text { Industry Dummies } \\
& + \text { Year Dummies }+\epsilon_{\mathrm{i}}
\end{aligned}
$$

PercentInd is the percent of independent directors on the board obtained from RiskMetrics. RiskMetrics provides a board member's status as an employee/insider, linked (e.g., an employee of a supplier or customer), not ascertainable, and independent. Only board members listed as "independent" by RiskMetrics are identified as independent, and all other designations are considered not independent for purposes of this study. This definition is consistent with the application of board independence in prior literature (Armstrong, Core, \& Guay, 2014; Byard et al., 2006; Cai et al., 2009; Goh et al., 2016; Lehn et al., 2009; Linck et al., 2008). Armstrong et al. (2014) explains that directors may be classified as insiders, outsiders, or affiliates, also referred to as "gray" directors. Relationships such as former management, relatives of executives, and interlocking boards are also considered. However, firms must disclose, in accordance with Item 470(a), Regulation S-K, whether each director meets their firm's stock exchange definition of "independent" (Armstrong et al., 2014).

Information asymmetry is proxied by one of three variables, StickySGA, PctSpread, and ForecastError. StickySGA is the log of the change in percentage of SG\&A costs for the most recent of the last 4 years with a decrease in sales, minus the log of the change in percentage of SG\&A costs for the most recent of the last 4 years with an increase in sales, following Weiss (2010). The StickySGA proxy is constructed so that higher values represent stickier costs. PctSpread, the bidask spread, is obtained from CRSP. It is an annual average of the rate of daily closing bid-ask spread divided by the closing stock price of the firm (Choe, Tian, \& Yin, 2014; Corwin \& Schultz, 2012). ForecastError is computed with data from IBES as the absolute value of the difference between the mean analysts' forecasted earnings per share and the actual earnings per share for the fiscal year end, divided by the stock price at the beginning of the last month of the fiscal year. InstOwnPerc is the percentage of institutional ownership obtained from the Thompson 13F database.

The test variables are isolated in this study because the control variables are computed following the model from Linck et al. (2008) that explains board independence. $L o g$ $M V E$ is the log of the market value of equity measuring size. DebtRatio is the long-term debt to total assets of the firm at the fiscal year-end. LogSegments is the logarithm of number of business segments at the fiscal year-end. FirmAge is the number of years since the firm was listed on CRSP, and FirmAgeSQ is that number squared. MTB is the market value of equity to book value of equity at the fiscal year-end. RDRatio is the ratio of R\&D expenditures to total assets (if missing, set to zero) at the fiscal year-end. RetStd is the standard deviation of monthly stock returns over the 12 months in the preceding fiscal year, obtained from Compustat. CEOOwn is the percent of firm's shares held by the CEO at fiscal year-end, obtained from RiskMetrics database. Director $O_{w n}$ is the average percent of firm's shares held by each nonexecutive director, obtained from ExecuComp database. Free cash flow, $F C F$, is derived following Lehn and Poulsen (1989): (operating income before depreciation) less (total income taxes, change in deferred taxes, interest expenses, preferred dividends on common stock divided by total assets). Perform is calculated as the average annual industry-adjusted mean return on assets over the 2 years preceding the proxy statements date obtained from Compustat database. CEOAge is the age of the CEO. LagCEOChair is a dummy variable equal to 1 if the CEO was chair of the board of directors in the prior year, obtained from RiskMetrics. CEOTenure is the number of years the executive has held this position, obtained from ExecuComp. Controls are included for industry effects using the 48 Fama and French (1997) industries and year effects from each year represented in the sample.

\subsection{Sample selection and data}

The sample dataset is compiled by extracting all firms from RiskMetrics which have information on board size and board independence for 2 years or more over the period 1999-2011. All firms with fewer than three board members are dropped in accordance with Linck et al. (2008). This initial sample is matched with the CRSP, Compustat, ExecuComp, IBES, and Thomson 13F Institutional Ownership databases. In addition, 
the sample is limited to unregulated U.S. firms by dropping financial and utility companies (SIC codes $49,60-69$ ) with annual financial data, monthly stock returns, analyst forecast data, and bid-ask prices for fiscal year following the 4 months after the fiscal-year-end. The final sample consists of 6,811 firm-years and 1,184 firms. The StickySGA-variable requires historical data that is not available for all firms, therefore, the models with StickySGA consist of 4,376 firm-years and 1,006 firms. Exhibit 1 summarizes the sample selection process.

\section{4 | RESULTS}

\section{1 | Descriptive statistics}

Descriptive statistics are provided in Exhibit 2.

Panel A in Exhibit 2 shows that the firms in the sample have mean total assets of $\$ 7,746$ million, market value (firm size) of $\$ 5,998$ million and debt ratio of $18.0 \%$. Panel $\mathrm{A}$ also shows that the median (mean) board independence (PercentInd) is 75 (72.8) percent. StickySGA costs are, on average, tightly managed within the sample as the mean $(0.9 \%)$ and median (6.2\%) are both positive, indicating that costs are, on average, slightly sticky, consistent with prior literature (Weiss, 2010). Firm age ranges from one to 67 years, with a median age of 18 years. The mean CEO ownership is $2.9 \%$, and the mean ownership by directors reaches just $0.6 \%$. Approximately $59 \%$ of the mean observations identify that the CEO was a chairperson of the board in the previous year. The median institutional ownership is $74 \%$.

In Exhibit 2, Panel B the distribution of board independence is examined over time. There is a larger representation of firms with complete data in the later years of the sample. There was a minimum of one outsider on every board and, in 2007 and 2008, there were at least three outsiders on every board (Column 2). At least one board member was a member of management for all sample firms in all years, but the maximum number of representatives from management varied from a high of 12 in years 1999 through 2001, to a low of 6 from 2008 through 2010 (Column 3). Board size (number of directors) has not changed much over time; the median board size was nine members in every year, but the minimum and maximum board sizes ranged from a minimum of 4 to 5 members, and a maximum that varies from 15 to 19 board members. The median number of outsiders on the board increased from 6 members in 1999 to 7 members in 2011, and the median number of managers on the board decreased from 3 members in 1999 to 2 members in 2011. Percentage of independent board members, shown in the last column of Panel B, grew steadily from a mean of $63 \%$ in 1999 to $79 \%$ in 2011 . Even after 2003, in the post-SOX period, board independence for individual firms was as low as $13 \%$ in 2004 and $14 \%$ in 2009 .

\section{EXHIBIT 1 Sample selection}

$\begin{array}{ll}\text { All firm-year observations in RiskMetrics (1998-2011) } & 21,090 \\ \begin{array}{l}\text { Less: Observations without CRSP/COMPUSTAT } \\ \text { merged database or IBES data }\end{array} & (4,772) \\ \text { Less: Observations with missing data } & (7,742) \\ \text { Less: Firms in regulated or financial industries (SIC } & (1,235) \\ \quad \text { codes 4,900-4,999 and 6,000-6,999) } & \\ \text { Less: Observations without institutional ownership } & (530) \\ \quad \text { Initial sample } & 6,811 \\ \text { Less: Observations without StickySGA costs } & (2,435) \\ \quad \text { Final sample for models with StickySGA costs } & 4,376\end{array}$

Maximum board independence was between 92 and $94 \%$ in all years.

Exhibit 2, Panel C shows the number of firms with three or more members of management on the board. There are fewer insiders and more independent members on firm boards over time. In 2011, $19 \%$ of firms had three or more insiders on their board of directors, down from $62 \%$ in 1999. Although regulation has increased board independence, there is still considerable variation in board independence.

Exhibit 2, Panel D shows the distribution of institutional ownership membership from 1999-2011. The mean percent column shows that institutional ownership has been steadily increasing from the average of $57 \%$ in 1999 to the mean of $79 \%$ in 2011.

\section{2 | Correlations}

Correlation between the dependent variable, board independence (PercentInd), and the test proxies is provided in Exhibit 3.

The StickySGA variable has a significant negative correlation with PercentInd (correlation $=-0.047, p<0.01$ ), which means that stickier costs are associated with a lower percentage of board independence. PctSpread is negatively correlated with PercentInd (correlation $=0.181, p<0.01$ ), indicating that board independence increases with decreasing bid-ask spread. ForecastError (correlation $=0.019$ ) is not significantly correlated with PercentInd. InstOwnPerc is positively correlated with PercentInd (correlation $=0.29, p<0.01$ ) suggesting that board independence increases with higher institutional ownership in the firm.

\section{3 | Multivariate regressions}

In Exhibit 4, the equation for PercentInd is estimated, and the information asymmetry variables are added: StickySGA, PctSpread, and ForecastError.

For each measure of information asymmetry, four models are estimated. In the first column, a control for institutional 
EXHIBIT 2 Descriptive statistics

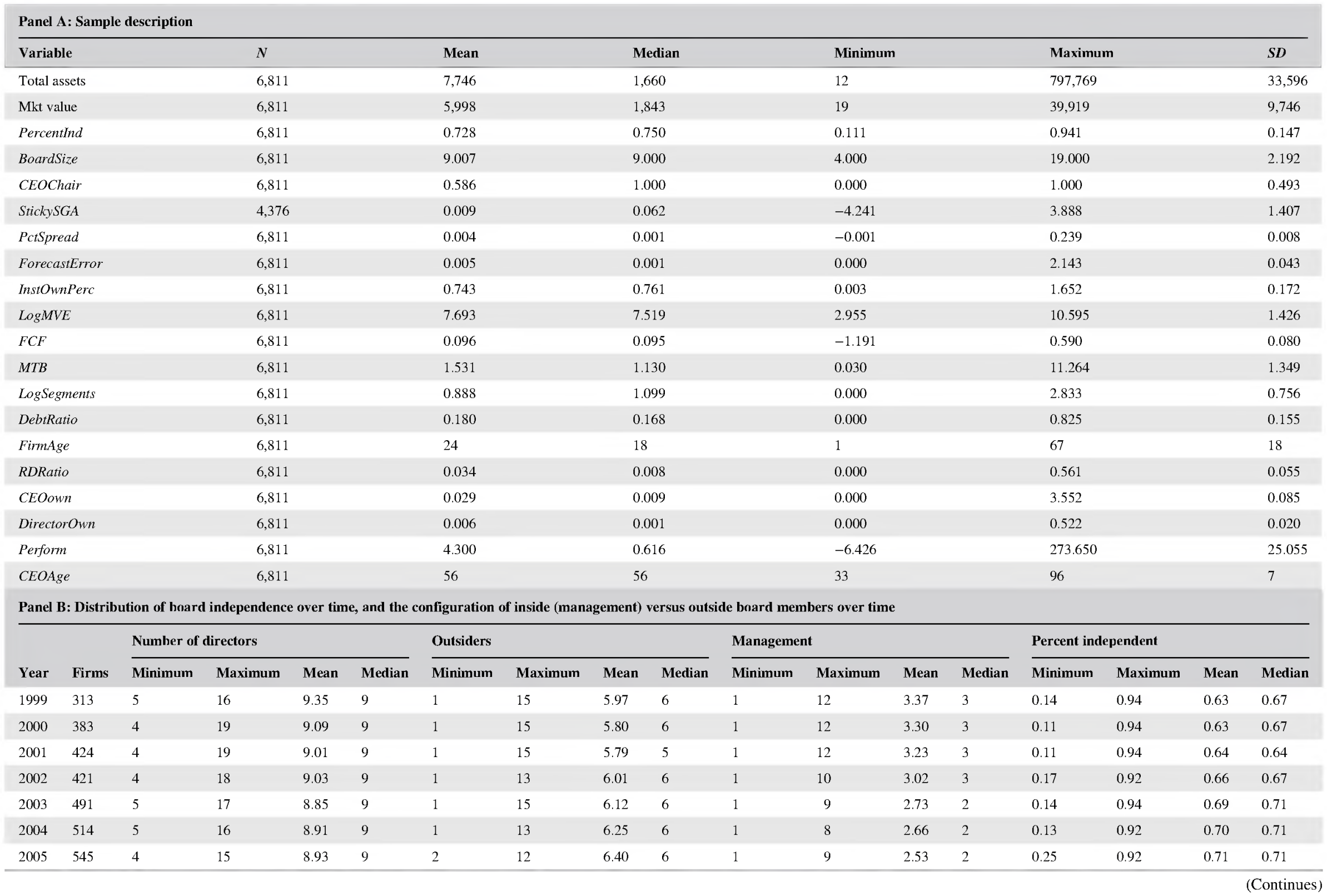


EXHIBIT 2 Continued

Panel B: Distribution of board indep endence over time, and the configuration of inside (management) versus outside board members over tine

\begin{tabular}{|c|c|c|c|c|c|c|c|c|c|c|c|c|c|c|c|c|c|}
\hline \multirow[b]{2}{*}{ Year } & \multirow[b]{2}{*}{ Firms } & \multicolumn{4}{|c|}{ Number of directors } & \multicolumn{4}{|l|}{ Outsiders } & \multicolumn{4}{|c|}{ Management } & \multicolumn{4}{|c|}{ Percent independent } \\
\hline & & Minimum & Maxímum & Mean & Median & Minimum & Maximum & Mean & Median & Minimum & Maximum & Mean & Median & Minimun & Maximum & Mean & Median \\
\hline 2006 & 564 & 4 & 17 & 9.07 & 9 & 2 & 13 & 6.62 & 6 & 1 & 7 & 2.45 & 2 & 0.33 & 0.93 & 0.73 & 0.75 \\
\hline 2007 & 558 & 4 & 17 & 8.98 & 9 & 3 & 15 & 6.91 & 7 & 1 & 8 & 2.07 & 2 & 0.27 & 0.93 & 0.77 & 0.78 \\
\hline 2008 & 607 & 5 & 16 & 9.00 & 9 & 3 & 13 & 7.10 & 7 & 1 & 6 & 1.90 & 2 & 0.44 & 0.93 & 0.78 & 0.80 \\
\hline 2009 & 650 & 4 & 15 & 9.00 & 9 & 1 & 14 & 7.14 & 7 & 1 & 6 & 1.86 & 2 & 0.14 & 0.93 & 0.79 & 0.80 \\
\hline 2010 & 682 & 4 & 17 & 9.00 & 9 & 2 & 16 & 7.18 & 7 & 1 & 6 & 1.82 & 2 & 0.44 & 0.94 & 0.79 & 0.82 \\
\hline 2011 & 659 & 4 & 18 & 9.04 & 9 & 2 & 16 & 7.22 & 7 & 1 & 10 & 1.82 & 2 & 0.41 & 0.93 & 0.79 & 0.82 \\
\hline
\end{tabular}

Panel C: Insider presence on boards

\begin{tabular}{|c|c|c|c|c|}
\hline Year & Size & $<3$ inside members & $3+$ inside members & Pct. $3+$ inside members \\
\hline 1999 & 313 & 119 & 194 & 0.62 \\
\hline 2000 & 383 & 137 & 246 & 0.64 \\
\hline 2001 & 424 & 156 & 268 & 0.63 \\
\hline 2002 & 421 & 182 & 239 & 0.57 \\
\hline 2003 & 491 & 249 & 242 & 0.49 \\
\hline 2004 & 514 & 266 & 248 & 0.48 \\
\hline 2005 & 545 & 306 & 239 & 0.44 \\
\hline 2006 & 564 & 321 & 243 & 0.43 \\
\hline 2007 & 558 & 395 & 163 & 0.29 \\
\hline 2008 & 607 & 470 & 137 & 0.23 \\
\hline 2009 & 650 & 511 & 139 & 0.21 \\
\hline 2010 & 682 & 552 & 130 & 0.19 \\
\hline 2011 & 659 & 533 & 126 & 0.19 \\
\hline
\end{tabular}

Panel D: Distribution of institutional ownership over time

\begin{tabular}{|c|c|c|c|c|c|}
\hline Year & Firms & Minimum & Maximum & Mean & Median \\
\hline 1999 & 313 & 0.09 & 0.92 & 0.57 & 0.60 \\
\hline 2000 & 383 & 0.09 & 0.94 & 0.60 & 0.62 \\
\hline 2001 & 424 & 0.09 & 0.97 & 0.61 & 0.63 \\
\hline 2002 & 421 & 0.21 & 0.97 & 0.66 & 0.68 \\
\hline 2003 & 491 & 0.24 & 1.10 & 0.69 & 0.70 \\
\hline
\end{tabular}




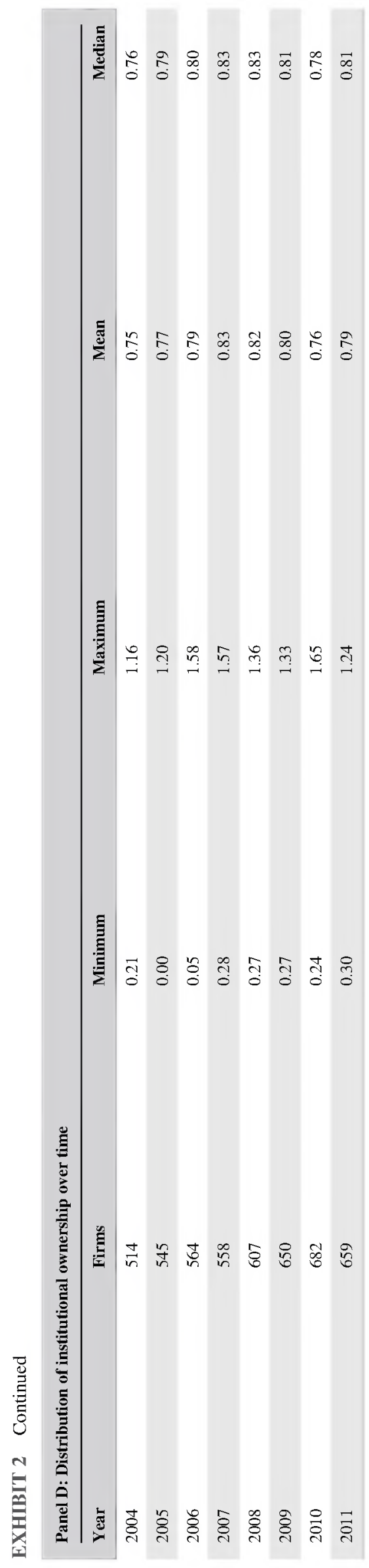

ownership is included, and in the second column the term for information asymmetry interacted with institutional ownership is added. In the third and fourth columns, the sample is split into observations below (Column 3) and above (Column 4) median institutional ownership.

In Exhibit 4, Panel A, higher StickySGA cost decreases board independence (coefficient $-0.0031, p$-value 0.0317), which means that firms with stickier SG\&A costs have a lower percentage of independent board members, supporting H1a. When StickySGA costs are interacted with the institutional ownership variable, the relationship is the opposite; the coefficient for StickySGA is -0.0158 , and the coefficient for StickyXInst is 0.0163. In other words, SG\&A costs in firms with higher institutional ownership are more sticky as board independence increases, supporting $\mathrm{H} 2$. The coefficient on StickyXInst has a higher absolute value (coefficient $=0.0163$ ) than the coefficient on StickySGA (coefficient $=-0.0158$ ), indicating that at high levels of institutional ownership, the effect of information asymmetry on board independence is reversed. In Columns 3 and 4, the sample is split into high and low institutional subsamples. Among firms with less than the median institutional ownership, StickySGA explains board independence at the $5 \%$ level (coefficient $=-0.0048$ ). However, in Model 4, the sample includes observations with institutional ownership above the median, and StickySGA is not significant in explaining board independence, indicating that in firms with high level institutional monitoring, in other words, more sophisticated ownership, sticky SG\&A costs do not influence board independence.

An evaluation of PctSpread, information asymmetry in the market, is shown in Exhibit 4, Panel B. In Column 1, PctSpread increases with board independence, supporting $\mathrm{H} 1 \mathrm{~b}$, that firms with a higher percentage bid-ask spread have more independent boards. This suggests that independent boards are associated with higher information asymmetry between the market and the firm. In Column 2, the institutional ownership variable is positively associated with board independence, however, the interaction term with institutional ownership is not significant. In Column 3, among firms with institutional ownership below the sample median, PctSpread is significant and positive, indicating that information asymmetry is higher with board independence. For firms with higher institutional ownership, in Column 4, PctSpread is no longer significant. While this result does not support $\mathrm{H} 2$, the regression in Column 3 shows that the association between board independence and information asymmetry is driven by firms with lower institutional ownership.

Exhibit 4, Panel $\mathrm{C}$ displays tests of information asymmetry attributed to analyst forecast error. A significantly positive association is detected between ForecastError and board independence in Column 1. A one percentage increase in ForecastError is associated with an increase of board independence of $10.15 \%$, 
EXHIBIT 3 Correlations

\begin{tabular}{lcccc} 
& PercentInd & StickyAvg & PctSpread & ForecastError \\
\hline StickySGA & $-0.047^{* * *}$ & & \\
PctSpread & $-0.181^{* * *}$ & $0.027^{*}$ & -0.018 \\
ForecastError & 0.018 & -0.007 & $-0.228^{* * *}$ & $-0.034^{* * * *}$ \\
InstOwnPerc & $0.290^{* * * *}$ & 0.015 &
\end{tabular}

This table displays the Pearson correlation coefficients for the dependent variables and test proxies employed in this investigation.

Significance at the $10 \%, 5 \%$, and $1 \%$ levels are designated as ${ }^{*},{ }^{*}$, and ${ }^{* * *}$, respectively.

\section{EXHIBIT 4 Information asymmetry and board independence}

\begin{tabular}{|c|c|c|c|c|c|c|c|c|}
\hline \multicolumn{9}{|c|}{ Dependent variable $=$ PercentInd } \\
\hline & \multicolumn{2}{|c|}{ All observations } & \multicolumn{2}{|c|}{ All observations } & \multicolumn{2}{|c|}{ InstOwnPerc < median } & \multicolumn{2}{|c|}{ InstOwnPerc $>$ median } \\
\hline & Est. & $p$-Value & Est. & $p$-Value & Est. & $p$-Value & Est. & $p$-Value \\
\hline Intercept & 0.6773 & $0.0001 * * *$ & 0.6808 & $0.0001 * * *$ & 0.8389 & $0.0001 * * *$ & 0.7757 & $0.0001 * * *$ \\
\hline StickyAvg & -0.0031 & $0.0317^{* *}$ & -0.0158 & $0.0073 * * *$ & -0.0048 & $0.0345^{* *}$ & -0.0014 & 0.3923 \\
\hline StickyXInst & & & 0.0163 & $0.0184 * *$ & & & & \\
\hline InstOwnPerc & 0.1430 & $0.0001^{* * *}$ & 0.1426 & $0.0001 * * *$ & & & & \\
\hline Control variables & Yes & & Yes & & Yes & & Yes & \\
\hline$R$ square & 0.3438 & & 0.3448 & & & 0.3627 & & 0.2897 \\
\hline Obs. & 4,376 & & 4,376 & & & 2,187 & & 2,198 \\
\hline \multicolumn{9}{|c|}{ Panel B: Percent spread } \\
\hline & Est. & $p$-Value & Est. & $p$-Value & Est. & $p$-Value & Est. & $p$-Value \\
\hline Intercept & 0.6631 & $0.0001 * * *$ & 0.6650 & $0.0001^{* * * *}$ & 0.8057 & $0.0001 * * *$ & 0.7660 & $0.0001 * * *$ \\
\hline PctSpread & 0.9440 & $0.0169 * *$ & 0.9126 & $0.0247^{* *}$ & 1.1078 & $0.0161 * *$ & -1.4702 & 0.1591 \\
\hline SpreadXInst & & & 0.0114 & 0.5775 & & & & \\
\hline InstOwn_Perc & 0.1325 & $0.0001 * * *$ & 0.1307 & $0.0001 * * *$ & & & & \\
\hline Control variables & Yes & & Yes & & Yes & & Yes & \\
\hline$R$ square & 0.3376 & & 0.3376 & & & 0.3529 & & 0.2647 \\
\hline Obs. & 6,811 & & 6,811 & & & 3,407 & & 3,404 \\
\hline \multicolumn{9}{|c|}{ Panel C: Forecast error } \\
\hline & Est. & $p$-Value & Est. & $p$-Value & Est. & $p$-Value & Est. & $p$-Value \\
\hline Intercept & 0.6798 & $0.0001 * * *$ & 0.6785 & $0.0001 * * *$ & 0.8295 & $0.0001 * * *$ & 0.7573 & $0.0001 * * *$ \\
\hline ForecastError & 0.1015 & $0.0390 * *$ & 0.1995 & $0.0034 * * *$ & 0.1073 & $0.0405^{* *}$ & 0.0630 & $0.0042 * * *$ \\
\hline ErrorXInst & & & -0.1585 & $0.0372^{* * *}$ & & & & \\
\hline InstOwn_Perc & 0.1305 & $0.0001 * * *$ & 0.1318 & $0.0001 * * *$ & & & & \\
\hline Control variables & Yes & & Yes & & Yes & & Yes & \\
\hline$R$ square & 0.3370 & & 0.3372 & & & 0.352 & & 0.2645 \\
\hline Obs. & 6,811 & & 6,811 & & & 3,407 & & 3,404 \\
\hline
\end{tabular}

This table shows the results of OLS regression with clustered errors for Equation (1). The dependent variable is PercentInd for all models; the percent of nonexecutive directors on the board. In Panel A, high (low) institutional ownership includes observations above (below) the sample median. Control variables from Equation (1) are untabulated, but are included in all models. Fama and French (1997) industry dummies and year effects are included in all models. *, **, and *** reflect significance at the 10,5 , and $1 \%$ levels. 
significant at the $5 \%$ level and supporting H1c. Furthermore, institutional ownership mitigates the information asymmetry as captured in the interaction term ErrorXInst (coefficient -0.1585, $p$-value 0.0372), supporting $\mathrm{H} 2$ in Column 2. The interaction of ForecastError with institutional ownership decreases board independence, suggesting that ForecastError decreases with increasing institutional ownership in the firm. In Columns 3 and 4, Panel C, ForecastError increases board independence in the subsamples of high and low institutional ownership, but the magnitude of the effect on board independence is stronger for firms with lower institutional ownership. The coefficient on information asymmetry due to analyst forecast error is higher (coefficient $=0.1073$ ) among firms in Column 3 and lower (coefficient $=0.0630$ ) in Column 4 .

Overall, the results in Exhibit 4 support the hypotheses. Firms with higher board independence are associated with lower information asymmetry internally, between management and the board (Panel A), and increased information asymmetry externally, with analysts and investors (Panels B and C). However, institutional ownership mitigates these associations. Stickier costs combined with institutional ownership explain increased board independence. For analysts and investors, information asymmetry combined with institutional ownership is lower as board independence is increased.

\subsection{Additional analysis}

An additional test was performed to evaluate the influence of information asymmetry and institutional ownership on board independence. The results of path analysis show that the direct effect (board independence and institutional ownership) is stronger than the indirect effect via the information asymmetry variable.

\section{I SUMMARY AND CONCLUSIONS}

An important component of the Sarbanes Oxley Act and NYSE stock exchange board regulation is the requirement that public firms increase the number of independent members in their board of directors (Armstrong et al., 2010). Outside board members, without managerial bias, add oversight to the managerial function to improve governance and represent shareholder interests. This research study finds that adding more diverse viewpoints to the board reduces agency costs in the form of sticky SG\&A, yet the increased oversight may come at the expense of reduced transparency for analysts and investors.

Furthermore, mitigating effects are identified on all three of these information asymmetry measures based on the extent of the firm's institutional ownership. In other words, firms with higher board independence are explained by higher bid-ask spread, higher analyst forecast error, and lower StickySGA costs, and firms with higher institutional ownership experience these effects to a lesser extent, or not at all.

In prior studies, researchers find that information asymmetry externally, between the firm and investors or analysts, reduced with board independence. One possible explanation for the findings in this study is that firms adopt board independence for the purpose of addressing information asymmetry. Prior literature concludes that increased board independence results in lower information asymmetry, therefore, firms with high information asymmetry choose a higher percentage of independent board members in response. Another explanation could be that most of the prior research does not control for institutional ownership, which, according to this study, has a significant, mitigating effect. Furthermore, including institutional ownership restricts the sample to a smaller set of larger firms. A third possible reason for the difference is that the sample in this study covers a longer period following SOX and Reg-FD.

An implication of these findings is that more board independence may not always be better. For example, as Maug (1997) shows, there is a cost to transferring inside information to external board members. Management has more expertise in managing the firm especially in high growth firms and complex industries such as technology. In that case, there is a trade-off between the cost of including another board member and the benefit of that member's trade expertise (Fama \& Jensen, 1983). The reason could be to reduce managerial perquisites, as board members whose seat was influenced by institutional sway use their board votes to reduce management's access to perquisites. A possible future research topic may be the determinant of an optimal level of board independence that is not equal to the maximum, but perhaps is dependent on factors such as industry and the firm's life cycle stage.

Few prior studies empirically examine information sharing between inside and outside board members. Internal information sharing is tested using Sticky SG\&A costs because they represent insider knowledge of expected future sales. An implication of this research is the identification of increased agency costs, representing increased information asymmetry between the board and firm management. SG\&A costs are stickier in firms with higher institutional ownership as independent board members are added. The findings in this study suggest that management resists communicating with board members selected by institutional owners, resulting in an agency cost to investors.

Institutional ownership plays an important role in the sharing of information both within the firm and between the firm and analysts. Higher board independence was mandated to improve investor confidence, but the findings in this study suggest that the benefits of board independence are not homogeneous. Increased board of director oversight, particularly for firms with less institutional ownership, is associated with less external transparency. Yet, as institutional ownership 
increases, agency costs are associated with more board independence. These results suggest that further research should be conducted on the influence of institutional ownership on board member selection and the relationship between management and board members appointed with institutional support.

\section{1 | Limitations}

This research should be interpreted cautiously. First, this study does not ascertain that the relationship between board independence, information asymmetry, and institutional ownership is causal. Armstrong et al. (2014) examine the endogenous relationship between board independence and information asymmetry. A second limitation of this study is that the methodology captures a marginal relationship. The findings in this study identify changes in board independence relative to the baseline levels of board independence and institutional ownership in the sample. For example, the sample does not include any firms with zero board independence. Although this study finds that board independence is associated with an increase in information asymmetry, the conclusion does not follow that all outside board members impair transparency. This limitation, likewise, exists for institutional ownership. Although this study finds that institutional ownership improves information asymmetry, the conclusion does not follow that institutional ownership should be maximized for that purpose.

\section{DATA ACCESSIBILITY}

The data used in this study is publicly available by subscribing to the products sold by the providers. Since the source data is proprietary, the database cannot be distributed.

\section{REFERENCES}

Adams, R., \& Ferreira, D. (2007). A theory of friendly boards. Journal of Finance, 62, 217-250.

Agrawal, A., Chadha, S., \& Chen, M. A. (2006). Who is afraid of Reg FD? The behavior and performance of sell side analysts following the SEC's fair disclosure rules. The Journal of Business, 79(6), 2811-2834.

Aguilar, L. A. (2013). Speech on April 19, 2013 by SEC Commissioner Luis A. Atlanta, GA: Aguilar at Georgia State University. Retrieved from http://www.sec.gov/News/Speech/Detail/Speech/ 1365171515808\#.VPz1Q7HD-M8

Akins, B. K., Ng, J., \& Verdi, R. S. (2012). Investor competition over information and the pricing of information asymmetry. The Accounting Review, 87(1), 35-58.

Anderson, M., Banker, R., Huang, R., \& Janakiraman, S. (2007). Cost behavior and fundamental analysis of SG\&a Costs. Journal of Accounting, Auditing and Finance, 22(1), 1-28.

Armstrong, C., Guay, W., \& Weber, J. (2010). The role of information and financial reporting in corporate governance and debt contracting. Journal of Accounting and Economics, 50, 179-234.
Armstrong, C. S., Core, J. E., \& Guay, W. R. (2014). Do independent directors cause improvements in firm transparency? Journal of Financial Economics, 113(3), 383-403.

Baumgarten, D., Bonenkamp, U., \& Homburg, C. (2010). The information content of the SG\&a Ratio. Journal of Management Accounting Research, 22, 1-22.

Bebchuk, L. A. (2005). The case for increasing shareholder power. Harvard Law Review, 118, 833-914.

Bebchuk, L. A., Fried, J. M., \& Walker, D. I. (2002). Managerial power and rent extraction in the design of executive compensation. The University of Chicago Law Review, 69(3), 751-846.

Benoit, D., \& Jargon, J. (2014). Darden restaurants CEO, chairman to step down. Wall Street Journal (July 28, 2014). Retrieved from https://www.wsj.com/articles/darden-chairman-ceo-to-step-down1406581334.

Bertrand, M., \& Mullainathan, S. (2003). Enjoying the quiet life? Corporate governance and managerial preferences. Journal of Political Economy, 111(5), 1043-1075.

Boone, A. L., Field, L. C., Karporr, J. M. \& Raheja, C. G. (2007). The determinants of corporate board size and composition: An empirical analysis. Journal of Financial Economics, 85(1), 66-101.

Bruggen, A., \& Zehnder, J. O. (2014). SG\&A cost stickiness and equity-based executive compensation: Does empire building matter? Journal of Management Control, 25, 169-192.

Byard, D., Li, Y., \& Weintrop, J. (2006). Corporate governance and the quality of financial analysts' information. Journal of Accounting and Public Policy, 25, 609-625.

Cai, J., Garner, J., \& Walkling, R. (2009). Electing directors. Journal of Finance, 64(5), 2389-2421.

Chen, C. X., Lu, H., \& Sougiannis, T. (2012). The agency problem, corporate governance, and the asymmetrical behavior of selling, general, and administrative costs. Contemporary Accounting Research, 29(1), 252-282.

Chen, X., \& Yur-Austin, J. (2007). Re-measuring agency costs: The effectiveness of blockholders. The Quarterly Review of Economics and Finance, 47, 588-601.

Cheng, Q., Luo, T., \& Yue, H. (2013). Managerial incentives and management forecast precision. The Accounting Review, 88(5), 1575-1602.

Choe, C., Tian, G. Y., \& Yin, X. (2014). CEO power and the structure of CEO pay. Intemational Review of Financial Analysis, 35, 237-248.

Coles, J. L., Daniel, N. D., \& Naveen, L. (2008). Boards: Does one size fit all? Journal of Financial Economics, 87(2), 329-356.

Corwin, S., \& Schultz, P. (2012). A simple way to estimate bid-ask spreads from daily high and low prices. Journal of Finance, 67(2), 719-760.

Davidoff, S. (2013). The case against too much independence on the board. New York Times (November 12, 2013). F-12.

D'Innocenzio, A. (2014). ISS seeks ouster of most of target's board. SeattleTimes.com (May 28, 2014). Retrieved from http://www. seattletimes.com/business/iss-seeks-ouster-of-most-of-targets-board/

Fama, E. F., \& French, K. R. (1997). Industry costs of equity. Journal of Financial Economics, 43(2), 153-193.

Fama, E. F., \& Jensen, M. C. (1983). Separation of ownership and control. The Journal of Law and Economics, 26(2), 301-325.

Fehle, F. (2004). Bid-ask spreads and institutional ownership. Review of Quantitative Finance and Accounting, 22, 275-292.

Florackis, C., \& Ozkan, A. (2009). The impact of managerial entrenchment on agency costs: An empirical investigation using UK panel data. European Financial Management, 15(3), 497-528. 
Goh, B. W., Lee, J., Ng, J., \& Ow Yong, K. (2016). The effect of board independence on information asymmetry. European Accounting Review, 25(1), 155-182.

Gomes, A., Gorton, G., \& Madureira, L. (2007). SEC regulation fair disclosure, information, and the cost of capital. Journal of Corporate Finance, 13(2), 300-334.

Grinstein, Y., \& Hribar, P. (2004). CEO compensation and incentives: Evidence from M\&A Bonuses. Journal of Financial Economics, 73, 119-143.

Guest, P. M. (2008). The determinants of board size and composition: Evidence from the UK. Journal of Corporate Finance, 14(1), 51-72.

Harford, J., \& Li, K. (2007). Decoupling CEO wealth and firm performance: The case of acquiring CEOs. The Journal of Finance, 62 (2), 917-949.

Harris, M., \& Raviv, A. (2006). A theory of board control and size. The Review of Financial Studies, 21(4), 1797-1832.

Jelinek, K., \& Stuerke, P. (2009). The nonlinear relation between agency costs and managerial equity ownership. International Journal of Managerial Finance, 5(2), 156-178.

Kanagaretnam, K., Lobo, G. J., \& Whalen, D. J. (2007). Does good corporate governance reduce information asymmetry around quarterly earnings announcements? Journal of Accounting and Public Policy, 26, 497-522.

Koo, J. (2011). The effect of corporate governance on the asymmetric cost behavior: Focusing on managers' ownership, foreign investor's ownership and institutional investor's ownership. Korean Journal of Management Accounting Research, 11(1), 1-35.

Lehn, K., \& Poulsen, A. (1989). Free cash flow and stockholder gains in going private transactions. The Journal of Finance, 44(3), 771-787.

Lehn, K. M., Patro, S., \& Zhao, M. (2009). Determinants of the size and composition of U.S. corporate boards: 1935-2000. Financial Management, 38(4), 747-780.

Linck, J., Netter, J., \& Yang, T. (2008). The determinants of board structure. Journal of Financial Economics, 87, 308-328.

Maug, E. (1997). Boards of directors and capital structure: Alternative forms of corporate restructuring. Journal of Corporate Finance, 3 (2), 113-139.

McCahery, J. A., Sautner, Z., \& Starks, L. T. (2016). Behind the scenes: The corporate governance preferences of institutional investors. The Journal of Finance, 71(6), 2905-2932.

Mohanram, P. S., \& Sunder, S. V. (2006). How has regulation FD affected the operations of financial analysts? Contemporary Accounting Research, 23(2), 491-525.

Raheja, C. G. (2005). Determinants of board size and composition: A theory of corporate boards. Journal of Financial and Quantitative Analysis, 40(2), 283-306.
Rock, E. B. (2015). Institutional investors in corporate governance. Faculty scholarship. Paper 1458. Retrieved from http://scholarship. law.upenn.edu/faculty_scholarship/1458

Schmidt, C., \& Fahlenbrach, R. (2017). Do exogenous changes in passive institutional ownership affect corporate governance and firm value? Joumal of Financial Economics, 124(2), 285-306.

Schwartz-Ziv, M., \& Weisbach, M. S. (2013). What do boards really do? Evidence from minutes of board meetings. Journal of Financial Economics, 108(2), 349-366.

Shiah-Hou, S. R. (2011). Does management involvement in the board affect analysts' coverage and institutional holdings? Journal of Leadership, Accountability and Ethics, 8(4), 97-118.

Sidhu, B., Smith, T., Whaley, R. E., \& Willis, R. H. (2008). Regulation fair disclosure and the cost of adverse selection. Journal of Accounting Research, 46(3), 697-728.

Singh, M., \& Davidson, W., III. (2003). Agency costs, ownership structure and corporate governance mechanisms. Journal of Banking and Finance, 27, 793-816.

Smith, M. (1996). Shareholder activism by institutional investors: Evidence from CalPERS. Journal of Finance, 51, 227-252.

Straser, V. 2002. Regulation fair disclosure and information asymmetry (March 2002). Available at SSRN: https://ssrn.com/abstract=311303

Sur, S., Lvina, E., \& Magnan, M. (2013). Why do boards differ? Because owners do: Assessing ownership impact on board composition. Corporate Governance: An International Review, 21(4), 373-389.

Topaloglu, S. 2003. Institutional trading activity around earnings announcements: Evidence on the effects of regulation FD. Queen's University Working paper.

Weiss, D. (2010). Cost behavior and analysts' earnings forecasts. The Accounting Review, 85(4), 1441-1471.

Westphal, J. D., \& Bednar, M. K. (2008). The pacification of institutional investors. Administrative Science Quarterly, 53, $29-72$.

Withisuphakorn, P., \& Jiraporn, P. (2015). The effect of CEO power on the informativeness of stock prices: An empirical note. Working paper (downloaded: January, 2015). 